\title{
Flood, Livelihood Displacement, and Poverty in Nigeria: Plights of Flood Victims, 2012-2018
}

\author{
Joachim Chukwuma Okafor
}

\section{Contents}

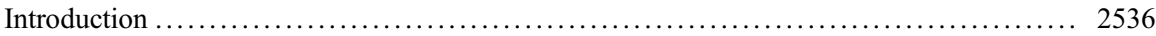

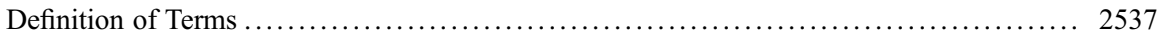

Method and Source of Data Collection and Analysis ............................ 2538

Reported Cases of Deaths, Population Displacement, Damages, and Victims

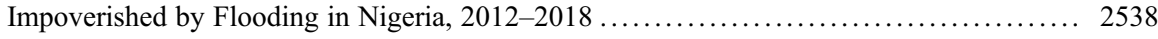

Government Responses to the Victims of Flooding and Challenges to Government

Responses to the Plight of Flood Victims in Nigeria .............................. 2544

Conclusion and Strategic Recommendations .................................. 2544

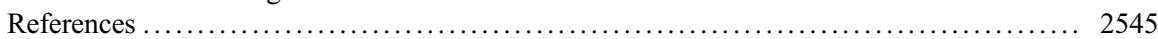

\section{Abstract}

The impacts of flood on the Nigerian population over the years have been enormous. This is because the attendant associated risks such as destruction of lives and properties, livelihood displacement, and impoverishment of victims arising from increasing flood cases have constituted a threat to the citizens' survival and therefore inform the attention the menace has drawn among scholars, policy analyst. This chapter has as its primary aim, a critical assessment of the impacts of government responses over the plight of victims of flooding in Nigeria over the years under review. Thus, special attention is given in this chapter to the various barriers or challenges facing government response to the plight of flood victims in Nigeria. Finally, some valuable steps, which if taken will reduce these

This chapter was previously published non-open access with exclusive rights reserved by the Publisher. It has been changed retrospectively to open access under a CC BY 4.0 license and the copyright holder is "The Author(s)". For further details, please see the license information at the end of the chapter.

J. C. Okafor $(\bowtie)$

Department of Political Science, University of Nigeria, Nsukka, Nigeria

e-mail: Chukwuma.okafor@unn.edu.ng 
barriers or challenges, are outlined. Though, the study adopted the use of secondary sources of data collection via content analysis, the experiences and knowledge gathered in this chapter will be strategically useful to people and organizations interested in the government of Nigeria's response to the plight of flood victims, barriers inhibiting the success of fund utilization in reducing the suffering and impoverishment of the flood victims, number of deaths, and population displaced as a result.

\section{Keywords}

Flood $\cdot$ Livelihood displacement $\cdot$ Poverty $\cdot$ Government responses $\cdot$ Flood victims

\section{Introduction}

Now in its sixth year, the threats the 2012 flood disaster along with the subsequent flood disasters that accompanied it posed on the livelihood of the victims in relation to the protracted impoverishment and displacement that these victims suffered while awaiting the government and private led humanitarian groups on relief materials have been the subject of debate among scholars, policy analysts, and climate change mitigation and adaptation experts (Nwodim 2016). The 2012 flood disaster in Nigeria that began in early July alone killed 363 people and displaced over 2.1 million people as of November 5, 2012 (Adekola and Lamond 2018).

According to the National Emergency Management Agency (NEMA), 30 out of the 36 states were affected by the floods. The floods were termed as the worst in Nigeria history in 40 years, and affected an estimated total of seven million people (Nkwunonwo 2016). The estimated damages and losses caused by the floods were worth 2.6 trillion naira (Cirella and Iyalomhe 2018). As rightly noted by Ndujihe (2018), flood disasters which followed the devastating 2012 event have the usual trend of submerging houses, deaths of people, population displacement, washing away of farmlands, and destruction of people sources of livelihood which have implications on the growing incident of impoverishment among affected Nigerian population. In fact, the 2018 flood disaster recorded in different states in Nigeria alone, especially from Bayelsa state, has been rated as the worst in the last 6 years (Akukwe et al. 2018).

In Nigeria, different factors have been deduced which account for the incessant cases of flood disaster in the country especially in states declared as the flashpoints for flood disaster (Nkwunonwo et al. 2016; Conversation 2017). First, climate change which causes global warming has been singled out as the basic factor that accounts for the increasing cases of flood disaster which has been shown to contribute to more extreme storms and rainfall. Another factor contributing to flooding in the country is that of the increasing rapid urban growth and poor drainage/culvert system planning. This chapter has as its objective the impacts of government response over these years on the plight of the flood victims. The assessment of the successive flood disasters from 2012 to 2018 on how it undermined livelihood, 
displaced population, destroyed farmlands, and foster impoverishment on the affected population. The rest of the chapter includes the introduction, definition of terms, method and sources of data collection and analysis, government response to the victims of floods in Nigeria, and protracted challenges facing the government in this regard.The reported cases of deaths, population displaced, damages and victims impoverished by flooding in Nigeria within the period under review. We draw conclusion with strategic recommendations.

\section{Definition of Terms}

The concepts of flood, livelihood displacement, poverty, government response, and victims of flood are pivotal in this discourse. Hence the definition of these terms will enhance a shared understanding of their usage in this discourse.

\section{- Flood:}

This is the outpouring or overflowing of water usually through rainfall which covers dry space and causes devastations on the socioeconomic activities of the people. Flood can occur through outburst of dam which releases much water on the dry spaces. Recent flood disasters in Nigeria have brought about the deaths of Nigerians, the washing away or destruction of farmlands, submerging of houses which heralds population displacement. Flood can be defined as an overflow of large quantities of water onto a normally dry land. Flooding happens in many ways due to overflow of streams, rivers, lakes, or oceans or as a result of excessive rainfall. Flood or flooding also destroys crops and can wipe away trees and other important structures on land.

- Livelihood displacement (LD):

Livelihood implies various means through which individuals secures a living. Livelihood also involves individuals or people assets, capabilities, income, and activities required to secure a living. Livelihood displacement encompasses threats that disarticulate or disrupt the operations of livelihood. In Nigeria, like in any other parts of the world, floods or flooding has proved to be the potent threat to livelihood displacement or disruption. Natural disasters like earthquake, hurricane, and climate change could become threat to livelihood displacement. In Nigeria, the 2012 flood disaster and the successive disasters have washed away cash crops and farmlands, fish pond, poultry business economic activities where people derived their livelihood.

- Poverty:

The displacement of people from their means of livelihood through flooding without the provision of relief material either from the government or private sector led humanitarian agencies to cushion the devastating impacts of the displacement could exarcerbated impoverishment among the victims of flooding. Poverty in this chapter means lack of capability or the capacity by the victims of flooding to provide for their basic necessities of life such as house, food, water, and healthcare, among others. 
- Government response (GR):

This is taking to mean, assistance, and support in the forms of relief materials given to the flood victims with the intention to reduce their sufferings brought about by flood disaster. In Nigeria, National Emergency Management Agency (NEMA) oversees and supervises the delivery of these relief materials across the Nigeria. Each state in Nigeria, for administrative convenience, has their respective State Emergency Management Agency (SEMA). Part of government response to the plight of flood victims in Nigeria is the release of fund. In 2012, the government under President Good luck Jonathan released the sum of 17.6 billion for the support of flood victims. Under President Muhammadu Buhari, the federal government has earmarked 1.6 billion each for the following states in the wake of the 2018 flood disaster across these states. The benefiting states are: Ekiti, Osun, Akwa Ibom, Kebbi, Niger, Kwara, Ebonyi, Enugu, Abia, Oyo, Lagos, Plateau, Sokoto, Edo, and Bayelsa.

- Flood victims (FV)

This is taking to mean individuals, groups, households, and communities that suffered from the devastating impacts of flood disaster. In Nigeria, there is victims support fund for flood disaster. Flood victims are person or persons whose houses were submerged by floods, farmland and livestock's destroyed, and source of livelihood is undermined or disrupted by flood disaster.

\section{Method and Source of Data Collection and Analysis}

This chapter adopted the documentary method of data collection that derived its base from the secondary sources of data gathering that include journal articles, newspapers, books, government publications, among others. The qualitative method of data analysis via content analysis was used to analyze the materials gathered from the secondary sources.

\section{Reported Cases of Deaths, Population Displacement, Damages, and Victims Impoverished by Flooding in Nigeria, 2012-2018}

From the year 2012 to 2018, the incident of flood disasters and its associated impacts on the victims of flood has been ernamours (Onwuka et al. 2015). Table 1 below covers the series of livelihood displaced, farmlands and cash crops washed away by flood, displaced people and livestock, impoverishment, and deaths, which occurred in Nigeria in some selected states. The logic behind the selection of these states was based on the declaration of the states as flashpoints or state vulnerable to flood disaster. 
Table 1 Shows reported cases of deaths, population displacement, damages and victims impoverished by flooding in Nigeria, 2012-2018

\begin{tabular}{|c|c|c|c|c|}
\hline $\begin{array}{l}\text { S/ } \\
\text { No. }\end{array}$ & State & $\begin{array}{l}\text { Month \& } \\
\text { year }\end{array}$ & $\begin{array}{l}\text { Reported cases of deaths, } \\
\text { displacement, damages, and } \\
\text { impoverishments of victims } \\
\text { by floods }\end{array}$ & Remarks \\
\hline 1. & Enugu & $\begin{array}{l}\text { March } \\
2018\end{array}$ & $\begin{array}{l}\text { Flood destroyed buildings, } \\
\text { killed a brick layer and } 2 \\
\text { students at Uhuowerre } \\
\text { community in Igbo Eze } \\
\text { South L.G.A in the state }\end{array}$ & $\begin{array}{l}\text { The flood incident destroyed } \\
\text { farmlands of villagers with } \\
\text { cash crops washed away by } \\
\text { marauding flood }\end{array}$ \\
\hline 2. & Ogun & June 2018 & $\begin{array}{l}\text { Farmers in Idagba area of } \\
\text { Ayetoro in Yewa L.G.A } \\
\text { recorded loss of lives and } \\
\text { fishes worth } 100 \text { million } \\
\text { naira to flood. Twelve } \\
\text { persons killed, } 3,800 \\
\text { displaced, } 200 \text { homes } \\
\text { destroyed in Abeokuta. } \\
\text { Areas affected in the city } \\
\text { include: Lafenwa, Ijaiye, } \\
\text { Kuto, Oke Lantoro, } \\
\text { Amolaso, Kobiti, and Ilawo }\end{array}$ & $\begin{array}{l}\text { The people whose source of } \\
\text { livelihood is tied to farming } \\
\text { have been threatened and } \\
\text { many became internally } \\
\text { displaced in the process }\end{array}$ \\
\hline 3. & Delta & July 2018 & $\begin{array}{l}\text { Flood submerged } 63 \\
\text { communities, destroyed } 43 \\
\text { houses in Koko, Warri } \\
\text { North, Araya, Isoko South } \\
\text { L.G.A. Agbarhor Ughelli } \\
\text { North and Oghara } \\
\text { communities in the state }\end{array}$ & $\begin{array}{l}\text { The flood was accompanied } \\
\text { with heavy downpour and } \\
\text { brainstorms }\end{array}$ \\
\hline 4. & Niger & July 2018 & $\begin{array}{l}\text { Twenty-three persons were } \\
\text { reported dead while bridges, } \\
\text { roads, and culverts linking } \\
\text { villages were destroyed. } \\
\text { Two persons were allegedly } \\
\text { missing }\end{array}$ & $\begin{array}{l}\text { The flood forced many } \\
\text { villagers out of their homes, } \\
\text { and economic activities } \\
\text { were severely halted }\end{array}$ \\
\hline 5. & Kano & $\begin{array}{l}\text { August } \\
2018\end{array}$ & $\begin{array}{l}\text { Eight local government } \\
\text { areas in the state were } \\
\text { affected, and hardest hit was } \\
\text { Kiru local government area } \\
\text { which recorded the deaths } \\
\text { of } 3 \text { persons }\end{array}$ & $\begin{array}{l}\text { Indigenes/residents of these } \\
\text { local areas are } \\
\text { predominantly farmers. The } \\
\text { flood halted their } \\
\text { livelihoods, and their } \\
\text { movement were restricted } \\
\text { for days thereby } \\
\text { undermining economic } \\
\text { activities }\end{array}$ \\
\hline 6. & Bayelsa & $\begin{array}{l}\text { October } \\
2018\end{array}$ & $\begin{array}{l}\text { Seventy percent of the } \\
\text { Bayelsan communities were } \\
\text { submerged by flood. The } \\
\text { hardest hit was communities } \\
\text { in Sagbama L.G.A. Many } \\
\text { persons were displaced. } \\
\text { These communities include }\end{array}$ & $\begin{array}{l}\text { The flood disaster led to } \\
\text { closure of schools }\end{array}$ \\
\hline
\end{tabular}


Table 1 (continued)

\begin{tabular}{|c|c|c|c|c|}
\hline $\begin{array}{l}\text { S/ } \\
\text { No. }\end{array}$ & State & $\begin{array}{l}\text { Month \& } \\
\text { year }\end{array}$ & $\begin{array}{l}\text { Reported cases of deaths, } \\
\text { displacement, damages, and } \\
\text { impoverishments of victims } \\
\text { by floods }\end{array}$ & Remarks \\
\hline & & & $\begin{array}{l}\text { Sampou, Kaiama, Bolou } \\
\text { Orua, Toru Orua, etc. }\end{array}$ & \\
\hline 7. & Lagos & July 2017 & $\begin{array}{l}\text { Homes and buildings were } \\
\text { submerged, movements } \\
\text { along the roads became } \\
\text { difficult in Lekki, Victoria } \\
\text { Island, Ajah and other cities } \\
\text { and towns in the state }\end{array}$ & $\begin{array}{l}\text { This flood halted economic } \\
\text { activities. Poor drainage } \\
\text { system and inadequate } \\
\text { urban planning were said to } \\
\text { be force multipliers of the } \\
\text { flood }\end{array}$ \\
\hline 8. & Benue & $\begin{array}{l}\text { August } \\
2017\end{array}$ & $\begin{array}{l}\text { An estimated } 1,000 \text { persons } \\
\text { were displaced, } 2,000 \\
\text { homes damaged and lives } \\
\text { lost. The flood is peculiar to } \\
\text { Benue state due to Benue } \\
\text { river and serial heavy } \\
\text { downpour as flashpoints } \\
\text { state }\end{array}$ & $\begin{array}{l}\text { Benue is known for } \\
\text { consistent agricultural } \\
\text { produce. Six Local } \\
\text { government areas affected } \\
\text { were Markudi, Agatu, } \\
\text { Guma, Tarka, Logo, and } \\
\text { Buruku }\end{array}$ \\
\hline 9. & Katsina & $\begin{array}{l}\text { August } \\
2017\end{array}$ & $\begin{array}{l}\text { According to the State } \\
\text { Emergency Management } \\
\text { Agency (SEMA), an } \\
\text { estimated } 1,000 \text { houses } \\
\text { were destroyed, many } \\
\text { displaced from their homes } \\
\text { and lives lost to flood in } \\
\text { Inwala Jangebe village in } \\
\text { Batagarawa, Kaita, } \\
\text { Malumfashi, Mabai village } \\
\text { of Kankara, and Kusada L. } \\
\text { G.As }\end{array}$ & $\begin{array}{l}\text { Majority affected by the } \\
\text { flood were rural farmers. } \\
\text { SEMA had distributed } 2 \\
\text { trailers of cement and } 600 \\
\text { bundles of roofing zinc to } \\
\text { the flood victims across the } \\
\text { L.G.As }\end{array}$ \\
\hline 10. & Imo & $\begin{array}{l}\text { October } \\
2017\end{array}$ & $\begin{array}{l}\text { The flood that occurred in } \\
\text { Umuohii village in Oboama } \\
\text { Autonomous community in } \\
\text { Ezinihitte Mbaise destroyed } \\
\text { buildings, farmlands, } \\
\text { livestock, and economic } \\
\text { trees }\end{array}$ & $\begin{array}{l}\text { The heavy downpour that } \\
\text { lasted for } 2 \text { days rendered } 50 \\
\text { household homeless }\end{array}$ \\
\hline 11. & Oyо & June 2017 & $\begin{array}{l}\text { Over } 3,000 \text { houses were } \\
\text { submerged as lives and } \\
\text { properties were destroyed in } \\
\text { Olodo, Oki, Akobo, } \\
\text { Onipepeye, Kute, Eleyele, } \\
\text { Ariyo, and Celestial Church } \\
\text { Orogun along University of } \\
\text { Ibadan-Ojo road in Ibadan } \\
\text { metropolis by heavy } \\
\text { downpour }\end{array}$ & $\begin{array}{l}\text { The Oyo state government } \\
\text { had promised to support the } \\
\text { affected residents and repair } \\
\text { roads, culverts, and } \\
\text { drainages. Absence of these } \\
\text { amenities widens the } \\
\text { damages from flooding }\end{array}$ \\
\hline
\end{tabular}


Table 1 (continued)

\begin{tabular}{|c|c|c|c|c|}
\hline $\begin{array}{l}\text { S/ } \\
\text { No. }\end{array}$ & State & $\begin{array}{l}\text { Month \& } \\
\text { year }\end{array}$ & $\begin{array}{l}\text { Reported cases of deaths, } \\
\text { displacement, damages, and } \\
\text { impoverishments of victims } \\
\text { by floods }\end{array}$ & Remarks \\
\hline 13. & Nassarawa & $\begin{array}{l}\text { August } \\
2016\end{array}$ & $\begin{array}{l}\text { Fifteen persons died, } 36 \\
\text { houses submerged, and } \\
\text { handful scores of people } \\
\text { missing in the flood disaster } \\
\text { in Mararaba, Gurku, } \\
\text { Kabayi, and Ado } \\
\text { communities in Karu L.G.A }\end{array}$ & $\begin{array}{l}\text { Nassarawa state is among } \\
\text { the flashpoint states warned } \\
\text { by NEMA of impending } \\
\text { flood disaster in the } \\
\text { beginning of the year }\end{array}$ \\
\hline 14. & Yobe & $\begin{array}{l}\text { August } \\
2016\end{array}$ & $\begin{array}{l}\text { The SEMA estimated that } \\
\text { about } 300 \text { houses were } \\
\text { destroyed; farmlands and } \\
\text { livestock were destroyed in } \\
\text { Jakusko and Adaya } \\
\text { communities by the flood } \\
\text { disaster. Other villages } \\
\text { affected by the flood include } \\
\text { Ngelzarma, Jajere, Nangere, } \\
\text { Buduwa, Nguru, Gashua, } \\
\text { Damagum, Dapchi, etc. }\end{array}$ & $\begin{array}{l}\text { Agrarian Yobe state is } \\
\text { among the frontline states } \\
\text { that Boko Haram had } \\
\text { caused havoc; flood } \\
\text { disasters intensified the } \\
\text { sufferings of the people. } \\
\text { Food, clothes, and building } \\
\text { materials were provided to } \\
\text { the victims by the state } \\
\text { government }\end{array}$ \\
\hline 15 & Sokoto & $\begin{array}{l}\text { August } \\
2016\end{array}$ & $\begin{array}{l}\text { Fifty houses were destroyed } \\
\text { in Bachaka village in Gudu } \\
\text { L.G.A by flood disaster } \\
\text { caused by early morning } \\
\text { downpour }\end{array}$ & $\begin{array}{l}\text { No loss of lives was } \\
\text { recorded but people } \\
\text { farmlands and crops worth } \\
\text { millions of naira were } \\
\text { destroyed thereby } \\
\text { aggravated the poverty of } \\
\text { the locals }\end{array}$ \\
\hline 16 & Bauchi & $\begin{array}{l}\text { August } \\
2016\end{array}$ & $\begin{array}{l}\text { Four persons died of flood } \\
\text { disaster in Galamakira and } \\
\text { Galam Baba communities in } \\
\text { Ganjuwa L.G.A. Eight } \\
\text { persons killed by flooding in } \\
\text { Gulbuk community in Giade } \\
\text { L.G.A }\end{array}$ & $\begin{array}{l}\text { Lack of access to primary } \\
\text { health care for those who } \\
\text { sustained injuries during the } \\
\text { emergency in these } \\
\text { localities was glaring }\end{array}$ \\
\hline 17 & Plateau & $\begin{array}{l}\text { August } \\
2016\end{array}$ & $\begin{array}{l}\text { All-night downpour } \\
\text { destroyed } 20 \text { cows by } \\
\text { herdsmen in Fobor- } \\
\text { Angware and Maza, houses } \\
\text { were destroyed, people in } \\
\text { Jos East L.G.A. Roads } \\
\text { linking communities were } \\
\text { also washed away by the } \\
\text { heavy flood }\end{array}$ & $\begin{array}{l}\text { Twenty-nine other cows } \\
\text { were discovered after the } \\
\text { flood disaster. Farmers lost } \\
\text { their sources of livelihood as } \\
\text { many farmlands were } \\
\text { destroyed by the flood }\end{array}$ \\
\hline 18 & Kano & $\begin{array}{l}\text { September } \\
2015\end{array}$ & $\begin{array}{l}\text { Six persons were killed in } \\
\text { Shanono, Dala, Tundu } \\
\text { Wada, Gabasawa, and Takai } \\
\text { L.G.As by flood and } 1,600 \\
\text { persons representing } \\
\text { families and properties }\end{array}$ & $\begin{array}{l}15.8 \text { million naira was said } \\
\text { to have earmarked for the } \\
\text { purchase of relief materials } \\
\text { for the support of the } \\
\text { victims }\end{array}$ \\
\hline
\end{tabular}


Table 1 (continued)

\begin{tabular}{|c|c|c|c|c|}
\hline $\begin{array}{l}\text { S/ } \\
\text { No. }\end{array}$ & State & $\begin{array}{l}\text { Month \& } \\
\text { year }\end{array}$ & $\begin{array}{l}\text { Reported cases of deaths, } \\
\text { displacement, damages, and } \\
\text { impoverishments of victims } \\
\text { by floods }\end{array}$ & Remarks \\
\hline & & & $\begin{array}{l}\text { worth millions were } \\
\text { displaced by flood disaster }\end{array}$ & \\
\hline 19 & Edo & $\begin{array}{l}\text { September } \\
2015\end{array}$ & $\begin{array}{l}\text { More than } 35 \text { communities } \\
\text { were submerged by flood in } \\
\text { Etsako East and Etsako } \\
\text { Central L.G.A. An } \\
\text { estimated } 30,000 \text { persons } \\
\text { were displaced on the two } \\
\text { divides, and farmlands with } \\
\text { cash crops were destroyed } \\
\text { by flooding. The affected } \\
\text { communities were Udaba, } \\
\text { Uneme, Usomegbe, } \\
\text { Anegbette, Uneme- } \\
\text { Ugwoyo, etc. }\end{array}$ & $\begin{array}{l}\text { Victims of the flood were } \\
\text { women and children who } \\
\text { were in dire need of health- } \\
\text { care facilities, foodstuff, } \\
\text { shelter, etc. }\end{array}$ \\
\hline 20 & Adamawa & $\begin{array}{l}\text { September } \\
2015\end{array}$ & $\begin{array}{l}\text { Seven communities in } 5 \\
\text { local governments' areas } \\
\text { were submerged by flood } \\
\text { that includes Guluk, } \\
\text { Shellenge, Lamurde, } \\
\text { Demsa, and Numan. } \\
\text { Borongo community was } \\
\text { the hardest hit communities. } \\
\text { People were displaced, and } \\
\text { properties and farmlands } \\
\text { were destroyed by flooding }\end{array}$ & $\begin{array}{l}\text { Alleged to have caused by } \\
\text { outburst flood water from } \\
\text { Kiri-Dam and heavy } \\
\text { downpour }\end{array}$ \\
\hline 21 & Ebonyi & $\begin{array}{l}\text { September } \\
2014\end{array}$ & $\begin{array}{l}\text { Over } 200 \text { houses were } \\
\text { submerged, families } \\
\text { displaced by flood, and } 2 \\
\text { persons killed as a result in } \\
\text { Onuebonyi Inyimagu, } \\
\text { Abakaliki, and Izzi local } \\
\text { government area }\end{array}$ & $\begin{array}{l}\text { The flood came as a result of } \\
\text { a 3-day downpour which } \\
\text { affected rice plantations plus } \\
\text { other farms input. Ebonyi } \\
\text { state is an agrarian state }\end{array}$ \\
\hline 22 & Kaduna & $\begin{array}{l}\text { September } \\
2014\end{array}$ & $\begin{array}{l}\text { The flood claimed the life of } \\
\text { a } 7 \text {-year-old girl Theresa } \\
\text { James at Anguwar Yelwa } \\
\text { community in Chikun L.G. } \\
\text { A. Other areas affected by } \\
\text { the flood include Unguwar } \\
\text { Rimi, Lere, Kachia, Kaduna } \\
\text { North \& South, Unguwar } \\
\text { Dosa, Zaria council, etc. }\end{array}$ & $\begin{array}{l}\text { The flood was said to have } \\
\text { caused by 2-day heavy } \\
\text { downpour }\end{array}$ \\
\hline 23 & Oyo & June 2014 & $\begin{array}{l}\text { Ten persons were killed in } \\
\text { Apete Ibadan when a } \\
\text { makeshift bridge was } \\
\text { collapsed by floodwater }\end{array}$ & $\begin{array}{l}\text { Oyo state is among the } \\
\text { flashpoints for high incident } \\
\text { of flooding in Nigeria }\end{array}$ \\
\hline
\end{tabular}


Table 1 (continued)

\begin{tabular}{|c|c|c|c|c|}
\hline $\begin{array}{l}\text { S/ } \\
\text { No. }\end{array}$ & State & $\begin{array}{l}\text { Month \& } \\
\text { year }\end{array}$ & $\begin{array}{l}\text { Reported cases of deaths, } \\
\text { displacement, damages, and } \\
\text { impoverishments of victims } \\
\text { by floods }\end{array}$ & Remarks \\
\hline 24 & Anambra & $\begin{array}{l}\text { November } \\
2013\end{array}$ & $\begin{array}{l}\text { An estimated } 1,000 \text { people } \\
\text { of the } 2012 \text { flood victims } \\
\text { lost their voter's card in } \\
\text { Ogbaru and Anambra East } \\
\text { L.G.A }\end{array}$ & $\begin{array}{l}\text { Anambra state is one of the } \\
\text { states in the federation } \\
\text { declared by NEMA as the } \\
\text { national disaster in the } \\
\text { country }\end{array}$ \\
\hline 25 & Kano & $\begin{array}{l}\text { August } \\
2013\end{array}$ & $\begin{array}{l}\text { Five hundred persons were } \\
\text { displaced by heavy } \\
\text { downpour, } 100 \text { homes } \\
\text { submerged, } 4 \text { person } \\
\text { missing }\end{array}$ & $\begin{array}{l}\text { Kano is the largest city in } \\
\text { northern Nigeria where } \\
\text { torrential rainfall is fairly } \\
\text { common and residents in } \\
\text { rural areas rely on } \\
\text { agriculture for their } \\
\text { livelihood }\end{array}$ \\
\hline 26 & Yobe & $\begin{array}{l}\text { August } \\
2013\end{array}$ & $\begin{array}{l}\text { Over } 300 \text { houses were } \\
\text { submerged and } 1,000 \\
\text { persons displaced by from } \\
\text { their homes. Areas affected } \\
\text { in the state are Potiskum, } \\
\text { Gashu'a, Nguru, Fika, } \\
\text { Gaidam, Damagum, and } \\
\text { Damaturu, the state capital }\end{array}$ & $\begin{array}{l}\text { The flood also destroyed } \\
\text { farmlands and crops }\end{array}$ \\
\hline 27 & $\begin{array}{l}\text { Cross } \\
\text { River }\end{array}$ & July 2012 & $\begin{array}{l}49,000 \text { people were } \\
\text { displaced by the flood. Over } \\
212 \text { communities, } 1,800 \\
\text { houses, } 82,361 \text { farmlands, } \\
13 \text { lives lost, } 13 \text { suffered } \\
\text { severe injuries, } 18 \text { markets, } \\
15 \text { churches, and } 13 \text { schools } \\
\text { were destroyed }\end{array}$ & $\begin{array}{l}\text { Agrarian communities } \\
\text { whose farmlands and cash } \\
\text { crops were destroyed } \\
\text { became vulnerable. One } \\
\text { among the states in Nigeria } \\
\text { affected by the } 2012 \\
\text { unprecedented flood } \\
\text { experience }\end{array}$ \\
\hline 28 & Plateau & July 2012 & $\begin{array}{l}\text { Thirty-nine persons were } \\
\text { killed by the flood and } 35 \\
\text { missing. An estimated } 200 \\
\text { homes were destroyed by } \\
\text { the flood, and } 3,000 \text { persons } \\
\text { were displaced }\end{array}$ & $\begin{array}{l}\text { Enlisted in the club of states } \\
\text { severely affected by the } \\
2012 \text { flood disaster }\end{array}$ \\
\hline 29 & Kogi & $\begin{array}{l}\text { September } \\
2012\end{array}$ & $\begin{array}{l}\text { An estimated } 623,900 \\
\text { persons were displaced and } \\
152,575 \text { hectares of } \\
\text { farmlands were destroyed } \\
\text { by the flood }\end{array}$ & $\begin{array}{l}\text { Flashpoints of states in } \\
\text { Nigeria that are flood } \\
\text { vulnerable }\end{array}$ \\
\hline 30. & Niger & $\begin{array}{l}\text { October } \\
2012\end{array}$ & $\begin{array}{l}\text { Over } 117 \text { communities } \\
\text { submerged by flood, } \\
663,000 \text { persons were } \\
\text { affected as the victims } \\
\text { displaced from their homes. } \\
\text { Farmlands destroyed and } \\
\text { cash crops uprooted by the } \\
\text { disaster }\end{array}$ & $\begin{array}{l}\text { The victims and displaced } \\
\text { persons in the various } \\
\text { resettlements camps in the } \\
\text { state appealed to the } \\
\text { government to make their stay } \\
\text { permanent. That is the degree } \\
\text { of frustrations experienced by } \\
\text { these flood victims }\end{array}$ \\
\hline
\end{tabular}

Source: Compiled by the Author 


\section{Government Responses to the Victims of Flooding and Challenges to Government Responses to the Plight of Flood Victims in Nigeria}

In meeting with the increasing humanitarian needs of the flood victims, the National Emergency Management Agency (NEMA) was established via Act 12 as amended by Act 50 of 1999, to manage disasters in Nigeria. Therefore, from inception, NEMA has been tackling disaster-related issues through the establishment of concrete structures and measures, such measures as the education of the public in order to raise their level of awareness and reduce the effects of disasters in the country. In each of the 36 states including the Federal Capital Territory, there exists the State Emergency Management Agency (SEMA). From 2012 to 2018 involving the administration of President Good luck Jonathan and the current administration of President Muhammad Buhari, various emergency interventionist funds have been given to the states affected by the flood disasters. Under the former President Goodluck Jonathan, the sum of 17.6 billion naira was shared to states by the federal government to states hard hit by flooding. Following the rampaging floods of 2018, the federal government released 1.6 billion naira to 16 states that benefited from the intervention. The states are Ekiti, Osun, Akwa Ibom, Kebbi, Niger, Kwara, Ebonyi, Enugu, Abia, Oyo, Lagos, Plateau, Sokoto, Edo, and Bayelsa.

Despite federal government efforts in ameliorating the humanitarian needs of the flood victims, in 2018, the government pledged $\$ 8.2$ million for relief efforts as well as declaring a state of emergency in four states, namely, Niger, Anambra, Kogi, and Delta States. NEMA set up five emergency operation centers to facilitate search and rescue operations and humanitarian support. Orji (2018) had revealed that the various efforts and program in rescue and support for the flood victims have faced huge practical challenges in reaching flood victims; however, these efforts have also reportedly been undermined by poor management, bad governance, and corruption. Other challenges derailing the government efforts in meeting with the humanitarian needs of the floods victims is failure on the part of successive government to plan and prepare for longterm solution to the crisis of flooding in the country. People mistrust on government ability to come to their rescue in the face of national disaster and inability of the Nigerian state to judiciously implement the provisions of disaster management plan. The widening gap in the interaction between the state (Federal Government) and various Civil Society Organisations (CSO) in the country have not been cordial.

\section{Conclusion and Strategic Recommendations}

We began the chapter with the position that the lives of the victims of floods in Nigeria from the illustrated cases in our Table 1 show that from 2012 to 2018, destruction of farmlands and cash crops, population displacement, deaths of many Nigerians and the wanton destruction of people livelihoods were devastating in Ngeria. With this, the following strategic recommendations are offered: 
- Nigerian government should develop a long-term strategic plan toward the rescue, support, and release of humanitarian needs of the population. The culture of reactive from the federal government toward the plight of the floods victims should be discouraged.

- Fund so released for meeting the demands and needs of the floods victims should be monitored by the federal government to avoid rascality, misuse of funds, and diversion of the fund for personal aggrandizement of their members.

- There should be appropriate climate-related education in order to sensitize the population on risks associated with the floods.

\section{References}

Adekola O, Lamond $\mathrm{J}$ (2018) A media framing analysis of urban flooding in Nigeria: current narratives and implications for policy. Reg Environ Chang 18:1145-1159

Akukwe TI, Krhoda GO, Oluoko-Odingo AA (2018) Floods and meal frequency: the situation in Anambra and Imo States, South-eastern region of Nigeria. Journal of Environmental Science, Toxicology anf Food Technology 12(6):22-30

Cirella GT, Iyalomhe FO (2018) Flooding conceptual review: sustainability-focalized best practices in Nigeria. Appl Sci 8(1558):2-14

Conversation (2017) Why flooding in Nigeria is a serious problem. https://theconversation.com/ why-flooding-in-nigeria-is-an-increasingly-serious-problem-82272

Ndujihe C (2018) Rain of Fury: Nigeria loses 141 lives to rainstorm, flood in 2018. https://www. vanguardngr.com/2018/08/rains-of-fury-nigeria-loses-141-lives-to-rainstorm-flood-in-2018

Nkwunonwo UC (2016) A review of flooding and flood risk reduction in Nigeria. Glob J Hum Soc Sci 16(2):22-42

Nkwunonwo UC, Whitworth M, Baily B (2016) Review article: a review and critical analysis of the efforts towards urban flood risk management in the Lagos region of Nigeria. Nat Hazards Earth Syst Sci 16:349-369

Nwodim O (2016) The 2012 flood and government policy response in the Niger Delta. J Polit Sci Leadersh Res 2(2):54-63

Onwuka SU, Ikekpeazu FO, Onuoha DC (2015) Assessment of the causes of 2012 floods in Aguleri and Umuleri, Anambra East local government area of Anambra state. Br J Environ Sci 3(1):43-57

Orji S (2018) It rains, it pours, and it floods: Nigeria's growing seasonal problem. African arguments. https://www.africanarguments.org/2018/11/15/nigeria-floods-growing-problem. November, 15 th

Open Access This chapter is licensed under the terms of the Creative Commons Attribution 4.0 International License (http://creativecommons.org/licenses/by/4.0/), which permits use, sharing, adaptation, distribution and reproduction in any medium or format, as long as you give appropriate credit to the original author(s) and the source, provide a link to the Creative Commons license and indicate if changes were made.

The images or other third party material in this chapter are included in the chapter's Creative Commons license, unless indicated otherwise in a credit line to the material. If material is not included in the chapter's Creative Commons license and your intended use is not permitted by statutory regulation or exceeds the permitted use, you will need to obtain permission directly from the copyright holder. 